\title{
REGARDING THE USERS OF FINANCIAL STATEMENTS AND THEIR INFORMATION NEEDS
}

\author{
Luca Mihaela, Teaching Assistant \\ UNIVERSITY OF BACAU
}

\section{Abstract:}

In order to satisfy the information needs of users from inside and outside the organizations, accounting elaborated a proper method of generalization and synthesizing of information it produces, which involved the development of some appropriate tools, known as financial statements. For users outside the company, these are often the only source of information available directly from the organization. The knowledge of the interests of different categories of users has an important role in trying to improve the quality of financial statements, which should allow taking correct decisions based on the financial position, the results of economic and financial activity and the changes in the financial position of the company.

Producer of specialized information, the accounting present a special offer. Logically, we must know "the product" users, the requirements imposed, inclusively the purpose for which each beneficiary will use this specialized information system [Horomnea, E., Fundamentele ştiințifice ale contabilității. Doctrină. Concepte. Lexicon, Ed. Tipo Moldova, Iaşi, 2008, p. 171].

The Framework for the Preparation and Presentation of Financial Statements presents a classification of different users of financial statements that include seven classes of users (investors, employees and groups that represent them, lenders and suppliers, customers, governments and their agencies and general public), with their information needs.

The reason for the absence of the managers in this classification is that, even they are interested in the information contained in the financial statements, they can anytime access additional management and financial information, that helps them carry out their planning, decision-making and control responsibilities. Moreover, the management has the ability to determine the form and the content of such additional information in order to meet his own needs.

\section{The internal users informing}

The internal users of financial information are represented by the managers (the leaders) of an organization, which can be grouped, according to general features of the responsibilities to be met, in:

- senior managers or top-managers (president, general director or board of directors, vice-president, commercial director - if he is directly subordinate to the general director and doesn't exist the position of vicepresident etc.), whose main skills are the strategic orientation of the organization as a whole, in line with the mission and objectives settled, and the formulation and implementation of efficient and effective strategies, their decisions being mostly strategic and tactical;

- middle managers (division manager, director of production - when exists the position of vice-president, head of department, head of service - if he has office heads like subordinate etc.), whose main skill is to ensuring the effectiveness of activities and the development of harmonious interhuman relations, their decisions being mostly current and tactical ;

- first line managers or supervisors (regional sales manager, assistant of the human resources manager, head of project team, head office, supervisor etc.), whose main skills are using tools and methods, concretely implementation of specific knowledges and management processes, their decisions being integrally current.

In conclusion, the managers have the responsibility for enterprise exploitation and the achievement of its objectives. In the small 
enterprises, the manager may coincide with the business owner.

As internal users of financial information, the managers won't expect and they are not limited to information in the financial statements. They have immediate and full access not only to public information of the company, but also to internal information from the organization. Their information needs are covered, essentially, through unpublished statements, prepared, not only on the basis of financial accounting, but also of managerial accounting.

Decision-making roles of managers, according to some opinions presented in the specialty literature, are four: entrepreneurs, disturbance regulators, resource distributors and negotiators.

It results that in their activities, managers have usually many and varied targets, often complex. These objectives may refer to best adapt the organization to the conditions it operates by changing the organizational structure or by introduction of some new products or by improving existing ones, finding the right response to an aggressive advertising campaign of a competitor, correct elaboration of budgets, deliver quality goods and services, realized with a minimum cost, maintaining an acceptable level of income, resolving the disputes existing in the company and between the company and its environment, increasing the number of available jobs, protecting the environment etc.

To ensure the success and survival in a competitive economic environment, the management needs to focus on two main objectives: profitability and liquidity. These indicators can be found in the explanatory notes to the financial statements.

An important role of managers is to make the reality existing in the organization compatible with the needs and expectations of other users.

The external users want to have more information about the organization and its activities, information they can trust for taking the best decisions, while managers are interested to public, when they are not forced through the law, only information that allow them to create a favorable image of the organization or information in a form that distort the economic and financial reality of the company (an important role in this latter case have the censors and/or financial auditors).

Although they benefits from information asymmetry in relation to external users, the managers pay particular attention to how the published information are perceived by them [Malciu, L., Cererea şi oferta de informații contabile, Ed. Economică, Bucureşti, 1998, p. 28]. The reason of this interest is the fact that the financial statements inform the third party over the managerial ability. In other words, the managers use the information from the financial statements, specially, not to make decisions, but to communicate.

\section{The external users and their information needs}

The financial statements are an important means through which accounting information is communicated to decisionmakers. For the users from outside the organization, these are often the only source of information available directly from the company.

In the following we present the information requirements of external users, correlated to the information offer by the economic institutions through their financial statements, strarting from the classification of the users in The Framework for the Preparation and Presentation of Financial Statements which grouped them into seven categories already mentioned in this article: investors, employees and groups that represent them, lenders and suppliers, customers, governments and their agencies and general public.

The International Accounting Standards Board (IASB) recognizes that not all user requirements can be satisfied by the financial statements. It follows, however, implicitly, that investors are privileged users. Therefore, satisfying their information needs will meet the needs of most other categories of users [Gîrbină, M.M., Bunea, Ş., Sinteze, studii de caz şi teste grilă privind aplicarea IAS (revizuite) - IFRS, Volumul I, Ed. CECCAR, Bucureşti, 2005, p. 22]. 
In what follows, we tried to present more detailed the information needs of external users of financial statements, the manner and the measure these are satisfied by the current content of the financial statements.

Investors (shareholders, associates), as providers of capital are concerned, primarily, over the risk of investment they have been committed or intends to engage and the profitability which it produces or will produce.

According to some authors opinion, the risk relates to uncertainty "that matters", the one who is able to influence the expectations of owners. In financial theory it is considered that the risk is divided into two parts: specific risk, which doesn't depends on the characteristics of value title, and systematic risk, which measures the sensitivity of the title at the market fluctuations and which, on a equilibrate market, is paid. Since the financial statements are not providing a direct assessment for this parameter, investors requires information that help them to measure it.

For a more accurate assessment of the risk-return relation, information like: financial profitability of the enterprise (calculated as ratio between the result and the equity), the earning per share (ratio between the net result and the number of shares), dividend per share (ratio between the value of dividends and the number of shares), price earning ratio (calculated as ratio between the exchange rate of share and the net result per share), the capitalization of profits ratio (calculated by reversing the terms of the previously ratio), global investment yield (calculated as ratio between the dividends per share and the exchange rate of share from the beginning of the financial year), have a great relevance for the investors.

Concretly, the investors are interested in the enterprise ability to achieve future earnings and to increase its wealth, taking into consideration the monetary flows released, which have a tangible representation, and less net benefit, which doesn't reflects always the real enrichment of the company. In conclusion, the information provided by the statement of cash-flows are more important for the investors than those offered through the income statement. Moreover, the preference for the increasing value of the enterprise make the statement of financial position to be privileged to the income statement.

A large number of studies on investors needs highlighted the interest of this group for forecasted information, making necessary the publication of some budgetary information in the completion of financial statements. These variant isn't applied in practice yet, probably at least two reasons: the future is uncertain, the disclosure of certain forecasted information may be contrary to the interests of the company when it acts in a competitive environment.

Even it is considered that the owners (shareholders/associates) are privileged users, aiming through the actual content of the financial statements, primarily, satisfying their information needs, it can be affirmed that they are not a homogeneous group and therefore will not be met equally their needs.

Thus, those who hold privileged shares and who hold ordinary shares doesn't have the same needs nor the same behaviour. Since privileged shares entitle to a fixed rate of dividends, their owners are more interested in profits safety (the part they obtain is a fixed rate no matter the profit level) than in the increase of business (by growth will benefit ordinary shareholders only) [Malciu, L., Cererea şi oferta de informații contabile, Ed. Economică, Bucureşti, 1998, p. 19].

In addition, the majority shareholders and minority shareholders do not always have the same power to impose their requirements. Also, investors differ in terms of ability to interpret information and therefore the demand of professional investors is different from that of non-professional investors. These are only some examples which show that investors' heterogeneity will lead, in consequence, to a heterogeneous information request.

The employees and the groups that represent them require, in general, relevant information on future prospects of the organization (stability, profitability etc.), on job security and validity of pension plans, on manners and levels of remuneration, on nature and extent of professional opportunities. Such 
information can help them to increase the involvement in the company, the interest in work.

The profitability, determined on the basis of the information offered by the income statement, reflected also in the balance sheet, is an essential piece of information in their preparation for negotiating the increases of the wages or the improving of working conditions and is also a premise for employment security. For employees and for investors it present interest not only the overall performance of the entity, but the performance of each sector, which help them to verify and understand the managers' decisions on the extension or restriction of particular activities.

In the explanatory note to the financial statements nomber 8 Information on the employees and members of the board, management and supervision, according to romanian accounting regulations, there must be mentioned some information which present interest for this category of users: the average number of the employees of the organization, detailed for each category, wages paid or payable in the current year, expenses on social security and other expenses for pension contributions.

Regarding professional opportunities, these information knowledges can stimulate the workers to follow different training programs, other than those offered through the organization, to continue their studies, aspects that will have a beneficial influence over the future business of the entity.

Sometimes the interest of the employees is oriented on information beyond the field of the financial accounting, such as the incidence over the working conditions of the production programme, the general evolution of the orders, the forcasted measures for improve, transform, replace the equipments or the methods of production and exploitation etc.

As a result of pressure coming from the employees and the unions over the businesses, in some countries of the world, became compulsory the preparation of a social balance that includes, in general, information on: the posts (efective posts, foreign workers, employments, departures, promotions, unemployment, absenteeism etc.), the remuneration and other related expenses (the total amount of remuneration, the remuneration hierarchy, the manner of calculation, other related expenses, the financial participation of employees etc.), the conditions of hygiene and safety (accidents at work and on road, the distribution of the accidents on material elements, occupational diseases, expenses for security etc.), other working conditions (the duration and organization of working time, the organization and content of work, the physical working conditions, the work medicine etc.), training, professional relations, other living conditions that depend on enterprise.

In the event that the company of our country would be compelled to draw up a social balance, it should contain, therefore, all areas that relate to the living conditions of employees in their work, giving value to positive aspects and shortcomings of social policy. Only part of the necessary information to be summarized here can be obtained through the accounting.

The lenders, namely banks and other credit institutions, in assuring the financing of the company, are primarily interested in its solvency, which meens its ability to repay the loans and interests on term, and does not grant loan without a rigorous analysis of the organization's financial situation and its performance, more specifically, an analysis of the liquidity and the profitability of the enterprise and the system of guarantees that may benefit.

To determ the capacity for repayment the loans it is necessary to valuate the assets and the liabilities of the enterprise, for prudential, to their liquidation value. Therefore, some values of the assets are reduced, others are ignored and the values of the liabilities are increased.

The estimation of earnings expected by the creditors, in other words the interest, is in line with the risks of lending operations. The determination of these risks can be achieved on the basis of information concerning: the personal, moral and technical value of managers; the general situation of the branch; the general situation of the enterprise (the nature, the quality, the price of the 
products, the key customers and suppliers, etc.) and other information obtained from inside or outside the company. As a rule, there are some preset levels of interest that choose between.

A particular attention is given to the liquidity and profitability indicators of the company. In this regard, the creditors assure that the short term loans arn't used to finance fixed assets, and the company has the ability to create profit, which is a guarantee of the ability of the company to repay on time the loans received and to pay related interests.

The guarantees required for giving credits may take various forms: real imobil guarantees (mortgages), real movable guarantees (pledges with or without dispossession), assignment of claims, letters of guarantee, payment instruments in bank circulation and endorsed in favor of suppliers etc.

Such information and further information can be obtained directly from the financial statements of credited company or may be requested from the company concerned to obtain foreign financing (not all enterprises are willing to provide additional information, giving a particular importance to the nature of these information).

The suppliers are primarily interested to check the measure to which the debtor company will be able to carry out its financial obligations, analyzing the solvency of the company and other information which allow the assessment of compliance with payment fixed date.

They also want to know what is the probability to continue the business, paying particular attention to development prospects of partners, which could have positive consequences in the future on their activities.

In the explanatory notes they find information regarding the compliance with or the breach of the going concern principle, and depending on the other information from the financial statements, from several years, they may appreciate the chances for economic growth of the enterprise.

The customers, like other users, need information to assess the continuity of the business and its growth prospects, in order to estimate the risks in their supply. Other information which present interest to them are those relating to the prices used by the company, the possibility to get some price reductions, the possibility to get after-sales services (such as maintenance, repairs), the maximum amount of commercial loans received, the time for pay accepted by the company etc.

The governments and their agencies have a dual role, on the one hand regulators of the accounting, and on the other hand users of the information contained in the financial statements.

As guarantor of the general interest, the state is directly or indirectly involved in the regulation of accounting, to provide users a minimum quality of information published and to attenuate the information asymmetry existing between different categories of users [Feleagă, N., Ionaşcu, I., Tratat de contabilitate financiară, vol. I, Ed. Economică, Bucureşti, 1998, p. 54].

The governments may settle to be presented in the financial statements other information than those existing or additional information for its own purposes, but to influence the financial statements in a manner that meet the needs of others users.

As a user, the state needs information, primarily for fiscality reasons, to determine the calculation of the base for taxes and follow the taxpayers pay them on time.

Fiscal legislation that applies to Romania is based on information provided by accounting, because the fiscal result is dependent upon the accounting result. The statement of financial position helps the control of the fiscal authority over the payment of the enterprise obligations on time and prevent fiscal evasion [Feleagă, N., Ionaşcu, I., Tratat de contabilitate financiară, vol. I, Ed. Economică, Bucureşti, 1998, p. 54].

Besides the above, the state needs information to assess the various demands regarding the offer of low interest grants or loans, to manage the national accounting, to prepare the statistics on the macroeconomic level, to make economic forecasts etc.

The general public is practically represented by any user that has not been mentioned explicitly in The Framework and 
which is interested in the accounting information produced within an economic organization.

For example, in this category of users can enter: polical responsibles of the local community concerned with the contribution of the company to the development of local economy by creating jobs, training employees etc.; the environmental and consumer protection movements attentive to the consequence of the business over the environment and over the quality of life; the researchers interested in the shape, content and quality of financial statements; the competing companies concerned with evaluating the position on the market; the consumers interested in whether exist or not a monopoly and the measure they could be exploited; the courts that give a particular attention to the legal evidence, dedicated to help in establish the truth and correct resolution of cases at the stage of research or judgment.

Of course, limiting the categories of users is not possible, because demand for information can come from any person who will base his decisions in accordance with the relation he has and the information he know about an economic agent. Moreover, in practice, these categories of users may be confused and may have a multiple position to the same company.

Analyzing the demand for accounting information coming from the different categories of users, it can see, the existence of common information needs (related to the solvency, profitability, liquidity, growth prospects of the company, business continuity etc.) and some distinct needs depending particularly on different vision on certain aspects.

Taking into account the requirements of different users, which are not satisfied by the current contents of the financial statements, we present some ways to improve the quality of information provided by the financial statements:

- providing forecasted information, in a normalized form to ensure the comparability over time and space, because the decisions taken on the basis of financial statements refers, in large part, to the future; in the normalization of the structure which provides forecasted information should be taken into consideration many factors, so that this presentation don't generate additional costs in the form of competitive disadvantages for the organizations, costs with installation of new reporting systems or other disadvantages;

- the obligation of preparation the statement of cash-flows by every legal persons, taking into account the distortions which affect the information in the income statement (due to the possibility of choosing between different methods of valuating the stock outputs, different periods, methods of amortization the fixed assets, the influence exerted by the fiscality etc.);

- developing a social balance by all economic companies, including, in a normalized form, the information in the explanatory note to the financial statements number 8 , and items that can not be expressed in value, but which presents interest to users, like information referring to the security of employment, the conditions to be met for promotion, the trainings, the professional relations, the conditions of hygiene and safety etc.;

- adding an additional explanatory note which present the risks over the organization and the estimations of adverse effects, as well as the actions taken to manage them;

- the specification by the regulators of some additional general information referring to the enterprise which should be presented in the explanatory note number 10 , even if these can't be value expressed. 


\section{References:}

[1] Cenar, I., Deaconu, S.C., Viața contabilă a întreprinderii de la constituire la faliment, Ed. CECCAR, Bucureşti, 2006

[2] Cotleț, D., Megan, O., Pelin, A., Pistol, I., Situațiile financiare - între informație şi decizie, Ed. Orizonturi Universitare, Timişoara, 2005

[3] Feleagă (Malciu), L., Feleagă, N., Contabilitate financiară - o abordare europeană şi internațională, Volumul I, Ed. InfoMega, Bucureşti, 2005

[4] Feleagă, N., Ionaşcu, I., Tratat de contabilitate financiară, vol. I, Ed. Economică, Bucureşti, 1998

[5] Gîrbină, M.M., Bunea, Ş., Sinteze, studii de caz şi teste grilă privind aplicarea IAS (revizuite) IFRS, Volumul I, Ed. CECCAR, Bucureşti, 2005

[6] Horomnea, E., Fundamentele ştiințifice ale contabilității. Doctrină. Concepte. Lexicon, Ed. Tipo Moldova, Iaşi, 2008

[7] Malciu, L., Cererea şi oferta de informații contabile, Ed. Economică, Bucureşti, 1998

[8] Mironiuc, M., Analiză economico-financiară, Ed. Sedcom Libris, Iaşi, 2006

[9] Nica, P., Iftimescu, A., Management. Concepte şi aplicații, Ed. Universităţii “Alexandru Ioan Cuza", Iaşi, 2003

[10] *** Standardele internaționale de raportare financiară (IFRS) 2007, incluzând Standardele internaționale de contabilitate (IAS) şi interpretări la 1 ianuarie 2007, CECCAR, Bucureşti, 2007

[11] *** Ordinul Ministerului Economiei şi Finanțelor nr. 2374/2007 privind modificarea şi completarea Ordinului ministrului finanțelor publice $n r .1 .752 / 2005$ pentru aprobarea reglementărilor contabile conforme $\mathrm{cu}$ directivele europene, publicat în Monitorul Oficial al României nr. 25 din 14 ianuarie 2008

[12] * * * Ordinul Ministerului Finanțelor Publice $n r .1752 / 2005$ privind aprobarea reglementărilor contabile conforme cu directivele europene, publicat în Monitorul Oficial al României nr. 1080 din 30 noiembrie 2005. 